\title{
ПРИМЕНЕНИЕ МЕТОДА ДИНАМИЧЕСКОГО РАССЕИВАНИЯ СВЕТА (ФОТОННОЙ КОРРЕЛЯЦИОННОЙ СПЕКТРОСКОПИИ) ДЛЯ ОПРЕДЕЛЕНИЯ РАДИУСА АССОЦИАТОВ ПОВЕРХНОСТНО-АКТИВНЫХ СОЕДИНЕНИЙ - ТРИТЕРПЕНОВЫХ САПОНИНОВ В ВОДНОМ РАСТВОРЕ
}

Мироненко Н.В., Смусева С.О., Калмыкова А.С., Селеменев В.Ф. Воронежский государственный университет svetlana_smuseva@mail.ru

DOI: 10.26902/ASFE-11_175

Новым направлением в создании материалов является получение самоорганизующихся структурированных на микро- и наноуровнях систем с уникальными свойствами. Движущими силами самоорганизации являются нековалетные межмолекулярные взаимодействия различной природы: гидрофобные, водородные связи, вандер-ваальсовые взаимодействия. Мицеллообразующие поверхностно-активные вещества (ПАВ) являются примерами таких систем.

Целью работы было исследование размеров агрегатов сапонина в водных растворах различных концентраций $0,43 \cdot 10^{-3}-2,17$ ммоль/дм ${ }^{3}$ (прибор Zetasizer Nano). Было установлено, что для каждой концентрации наблюдаются изменения размеров частиц в пределах от 499 до 2200 нм. Изменение концентрации растворенного вещества приводит к нелинейному изменению размеров системы. По-видимому, это связано c динамическим характером мицеллярной микрофазы, т. е. способностью к полиморфным превращениям.

Анализируя данные динамического рассеяния света в области разбавленных концентраций, можно отметить, что наблюдается бимодальная функция распределения. Следовательно, в водном растворе сапонина существую агрегаты нескольких размеров.

Очевидно, что в образовании наноассоциатов принимают участие молекулы воды, т. к. молекул только растворенного вещества просто недостаточно для образования агрегатов фиксируемого размера. Таким образом, можно предположить, поскольку размеры частиц в разбавленных растворах лежат в пределах от 400 нм до 1500 нм, то в области низких концентраций сапонина наблюдаются ассоциаты различных размеров, образованные гидратированными молекулами углеводной части сапонина, которые имеют динамический характер. Существование определенной структуры разбавленных растворов ПАВ-сапонина свидетельствует скорее о перестройке агломератов в области ККМ (критической концентрации мицеллообразования), a не о первоначальном формировании сферических мицелл в растворе.

Выявлено существование структур с гидродинамическими радиусами 1-50 нм, $\mathrm{r}=51-100$ нм и $\mathrm{r}=101-250$ нм в разбавленных растворах.

Начиная с концентрации 0,26 ммоль/дм³ ${ }^{3}$ в мицеллярном водном растворе сапонина наблюдается бимодальное поведение корреляционной кривой, следовательно, можно сделать вывод о том, что помимо имеющихся агрегатов появляются агрегаты, размеры которых больше 50 нм. Возможно, проявляемые биологические эффекты могут быть объяснены с позиции структурообразования в растворе.

\section{Сиисок литературь}

1. Mitra S., Dungan S. R. // J. Agric. Food Chem. 2001. Vol. 49. № 9. P. 384-394.

2. Mitra S., Dungan S. R // J. Agric. Food Chem. 1997. Vol. 45. № 5. P. 1587-1595.

Работа выполнена при поддержке Министерства науки и высшего образования РФ в рамках государственного задания ВУЗам в сфере научной деятельности на 2020-2022 годы, проект № FZGU-2020-0044. 